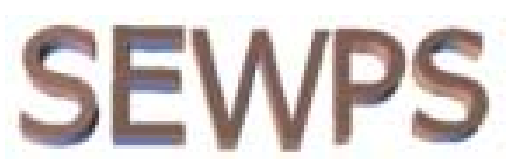

SPRU Electronic Working Paper Series

Paper No. 129

\title{
Exploiting the Oil-GDP Effect to Support Renewables Deployment
}

\author{
Shimon Awerbuch and Raphael Sauter
}

(SPRU)

January 2005 


\title{
EXPLOITING THE OIL-GDP EFFECT TO SUPPORT RENEWABLES DEPLOYMENT
}

\author{
Shimon Awerbuch, Ph.D. ${ }^{l}$ \\ Tyndall Centre Visiting Fellow \\ SPRU, University of Sussex \\ s.awerbuch@sussex.ac.uk \\ and \\ Raphael Sauter \\ Research Fellow \\ SPRU, University of Sussex
}

December 2004

SPRU Working Paper No. 129

\footnotetext{
${ }^{1}$ Portions of this paper previously appeared as an IEA Research Paper, (Paris, International Energy Agency, August 2002) where Awerbuch was Senior Advisor for Energy Economics, Finance and Technology and Sauter was a research assistant. This paper benefits from the suggestions of Morgan Bazilian, Sean Casten, Perry Sadorsky, Donald Aitken, and William Scally. We thank Steve Clemmer, Jeff Dyette and Alan Nogee of UCS for providing details of their analysis of the proposed US RPS. Remaining errors are of course our own.
} 


\begin{abstract}
The empirical evidence from a growing body of academic literature clearly suggests that oil price increases and volatility dampen macroeconomic growth by raising inflation and unemployment and by depressing the value of financial and other assets. Surprisingly, this issue seems to have received little attention from energy policy makers.

In percentage terms, the Oil-GDP effect is relatively small, producing losses in the order of $0.5 \%$ of GDP for a $10 \%$ oil price increase. In absolute terms however, even a $10 \%$ oil price rise - and oil has risen at least 50\% in the last year alone- produces GDP losses that, could they have been averted, would significantly offset the cost of increased RE deployment. While we focus on renewables, the GDP offset applies equally to energy efficiency, DSM and nuclear and other non-fossil technologies. This paper draws on the empirical Oil-GDP literature, which we summarize, to show that by displacing gas and oil, renewable energy investments can help nations avoid costly macroeconomic losses produced by the Oil-GDP effect.

We show that a $10 \%$ increase in RE share avoids GDP losses in the range of $\$ 29-\$ 53$ billion in the US and the EU (\$49-\$90 billion for OECD). These avoided losses offset one-fifth of the RE investment needs projected by the EREC and half the OECD investment projected by a G-8 Task Force. For the US, the figures further suggest that each additional $\mathrm{kW}$ of renewables, on average, avoids \$250-\$450 in GDP losses, a figure that varies across technologies as a function of annual capacity factors. We approximate that the offset is worth $\$ 200 / \mathrm{kW}$ for wind and solar and $\$ 800 / \mathrm{kW}$ for geothermal and biomass (and probably nuclear). The societal valuation of non-fossil alternatives needs to reflect the avoided GDP losses, whose benefit is not fully captured by private investors. This said, we fully recognize that wealth created in this manner does not directly form a pool of public funds that is easily earmarked for renewables support.
\end{abstract}

Finally, the Oil-GDP relationship has important implications for correctly estimating direct electricity generating cost for conventional and renewable alternatives and for developing more useful energy security and diversity concepts. We also address these issues.

KEYWORDS: Oil price shocks, oil price volatility, Oil-GDP effects, renewable energy, RES-E targets, financial beta risk, funding renewables. 


\section{Overview}

The empirical evidence from a growing body of academic literature clearly suggests that oil price increases and volatility dampen macroeconomic growth by raising inflation and unemployment and depressing the value of financial and other assets, at least in oil consuming nations. ${ }^{2}$ The idea that rising oil prices and their volatility stifle economic activity is not new. A quarter-century ago, the US Congressional Budget Office, under the leadership of Alice Rivlin, a highly regarded economist, estimated that the 1973 oil price increases cost the US economy \$350 billion [US Congressional Budget Office, 1981]. More recently Greene and Tishchishyna (2000) of Oak Ridge National Labs, estimated that from 1970 to 2000, oil price movements imposed up to $\$ 7$ trillion in costs on the US. ${ }^{3}$ By now, the negative relationship between oil prices/volatility and GDP is widely accepted in the literature and seems virtually axiomatic. For example, Yang et al. $(2002,107)$ flatly state "Higher [oil] prices [yield] subsequent recessions in oil consuming nations, as oil prices are negatively correlated to economic activities."

The so-called Oil-GDP relationship has been statistically measurable since the late 1940s (Jones et al., 2004) and although the empirical evidence has grown and become more significant in the last 20 years, energy policy makers have shown little interest in this literature or in the powerful implications of the negative Oil-GDP relationship. Perhaps they assume that dealing with the powerful fiscal and economic consequences of oil price shifts is in the purview of central bankers and finance ministers. Recent dramatic oil price increases and rising volatility however, seem to have brought the issue to the forefront. The news media routinely discusses the macroeconomic effects of recent oil price increases (e.g. Business Week, 2003, 2004a,b; The Economist, 2002, 2004a,b; FT, 2004a) while Alan Greenspan and other prominent economists (CNN, 2004) along with TV stock market pundits everywhere venture guesses about how the latest round of price increases (or decreases) will affect GDP and financial markets.

Even the IEA, which long ignored the issue, recently estimated that a $\$ 10$ oil price increase would lop $0.5 \%$ off global GDP creating \$255 billion in losses over several years (IEA, 2004). ${ }^{4}$ The IEA however makes no mention of the significant implications its estimate carries for renewable energy (RE) and other non-fossil technologies. In absolute terms, the magnitude of these figures is staggering. Yet economists and the press widely conclude that the economy will "shake off" such oil spike effects (e.g. CNN, 2004).

2 The literature tends to focus on consuming nations, although more recent evidence (e.g. IEA, 2004) applies globally.

${ }^{3}$ With $43 \%$ due to GDP losses, $31 \%$ to wealth transfers and $26 \%$ to macroeconomic adjustment losses.

$40.5 \%$ of world GDP is approximately $\$ 168$ billion. It also estimated losses for the Euro-zone of $0.5 \%$ of GDP and $0.4 \%$ in OECD countries over two years. 
While the percentages involved may seem small, the Oil-GDP effect has significant ramifications for RE that policy makers do not seem to grasp. ${ }^{5}$ For example, although US Energy Secretary Spencer Abraham sympathized that fossil price increases hurt people's pocketbooks and livelihoods (Reuters/Planetark, 2001), energy policy - in the US and elsewhere - clearly seems to have missed the seemingly straightforward idea that renewable energy mitigates exposure to such fossil risk and that this can help nations avoid costly economic losses. Reducing oil-dependency produces sizeable benefits (Lovins et al., 2004). Indeed our calculations show that RE investments in the US and the EU may be significantly offset by avoided Oil-GDP induced losses. It is difficult to comprehend such a massive energy policy failure that continues to ignore the powerful cost reduction and risk-mitigating benefits of renewables and efficiency. We focus on renewables, although the arguments apply equally to nuclear and other fossil-free technologies and energy efficiency.

Aspects of the risk-mitigating properties of renewables also serve to enhance their investment valuation in a capital-market theory context. The Oil-GDP relationship affects the value of renewables as well as the calculative procedures through which their value is estimated in the following principal ways:

a. The Oil-GDP relationship affects the procedures for correctly estimating the direct generating costs of renewable and fossil generating technologies. Analysts routinely estimate generating costs using discounted cash flow (DCF) procedures. The OilGDP relationship indirectly affects the discount rates used in this process, which in turn has the effect of producing significantly larger present value costs for fossil-based generation.

b. The Oil-GDP relationship affects how we conceptualize, define and attain energy diversity and security objectives. It suggests that as a pre-eminent security objective, policy makers promote the creation of efficient energy portfolios that minimize needless exposure to fossil risk.

c. The Oil-GDP relationship has important ramifications for the societal valuation of RE, energy efficiency and nuclear to the extent that these investments displace gas and oil, which reduces their market price and potentially their volatility. This in turn serves to avoid the negative effects of Oil-GDP relationship.

This is the principal focus of the paper. Based on our survey of the statistical evidence, we argue that economic wealth released by avoiding negative Oil-GDP consequences produces a source of funds for commercializing and further deploying renewables. We are not aware of any policy initiative that seeks to exploit the Oil-GDP relationship as a basis for both justifying renewables, which may have higher accounting costs as compared to conventional technologies, as well as for providing a source for funding their deployment.

A G8 Task Force recently estimated that achieving an $8.6 \%$ RE share of OECD electricity output (excluding large hydro) will require public investment of USD\$90-

\footnotetext{
5 Perhaps with the notable exception of Rodrigo Rato, IMF managing director, who recently called for alternative energy as a means of mitigating the Oil-GDP effect (Financial Times, 2004b). Energy policy makers may simply feel the Oil-GDP issue is properly the purview of monetarists and central bankers.
} 
$\$ 120$ billion over the next 10 years (G8 Report, 2001, 28). Similarly, the European Renewables Energy Council and the European Wind Energy Association (EREC, 2004; see also Zervos, 2004) estimate that $€ 140$ billion is needed in the EU over 10 years to achieve a $12 \% \mathrm{RE}$ target and $€ 443$ billion over 20 years for a $20 \%$ target (EREC, 2004).

We argue that these RE outlays will be subsidized or offset by avoided GDP losses. We calculate this offset using empirical oil-GDP elasticities from the literature, along with US-EIA and other studies that estimate the extent to which RE deployment lowers the market prices of gas. This enables us to calculate the reduced GDP loss expectations produced by increased RE shares.

Our results suggest that relatively modest 10\% RES-E (RE share-electricity) increases can avoid oil-induced GDP losses in the range of \$58 $-\$ 106$ billion for the US and EU combined, \$49-\$90 for the OECD and \$95-\$176 globally, although the last estimate may be considerably less reliable. This suggests that avoided Oil-GDP induced losses could largely offset projected RE outlay requirements estimated by EREC/EWEA and the G8.

The paper proceeds as follows. In Section II, we review the implications of the Oil-GDP relationship for valuing renewables and for developing meaningful concepts and measures of energy security and diversity. In Section III we review the relevant empirical literature on the Oil-GDP relationship. We apply the statistical evidence in Section IV and develop a set of plausible estimates of the extent to which further RE deployment, possibly through renewables targets and standards might mitigate economic losses induced by the Oil-GDP relationship. We generally find that additional RE deployment outlays are, to a significant extent, offset by avoided wealth losses that would otherwise be incurred through the oil-GDP effect. We conclude in Section V.

\section{How the Oil-GDP Relationship Affects Electricity Generating Cost Estimates and Energy Security/Diversity Concepts}

The macroeconomic Oil-GDP relationship has direct microeconomic and financial consequences that affect the relative value of fossil-fired generation as compared to renewables. Energy planners routinely use discounted cash flow (DCF) procedures to produce electricity generating cost estimates. These are invariably based on arbitrary discount rates, and hence produce results with no economic interpretation (Awerbuch, 2003a,b). The Capital Asset Pricing Model (CAPM), a part of modern finance theory, provides a more reliable means for estimating discount rates for fossil fuel and other generating cost components on the basis of estimated fossil fuel betas (Awerbuch, 1993, 1995, 2000, 2003a,b). Correctly applied, the CAPM shows generating costs for gas-fired plant that are considerably higher than traditional estimates obtained using arbitrary engineering discount rates. 
Beta, a measure of financial covariance risk, provides the basis for estimating discount rates for generating projects. CAPM discount rates are a simple linear function of beta. ${ }^{6}$ The negative macroeconomic relationship between oil prices and GDP gives rise to the expectation that fossil fuel cash flow betas will also be negative. Indeed a number of researchers (Kahn and Stoft, 1993; Awerbuch, 1993, 1995; Bolinger et al., 2004) have reported empirically estimated cash flow betas for oil and gas that are negative. ${ }^{7}$ This means that the true cost of fossil generation far exceeds commonly held beliefs. It also means that future outlay streams for gas and other fossil fuels are highly risky for project developers, although history suggests that most of this risk is passed through to electricity consumers.

A negative fossil fuel beta implies a required discount rate below the risk free rate of returncurrently in the range of $3 \%$ for the US and many EU countries. ${ }^{8}$ Yet fossil generating costs are widely estimated using arbitrary discounts in the range of $5 \%-10 \%$ (e.g. see IEA/NEA/OECD, 1998) and even 15\% (see DTI, 2003). Higher discount rates yield lower present values that dramatically understate the true cost of fossil-based generation (e.g. Awerbuch, 1993, 1995, 2000, 2003a,b). The Oil-GDP effect has microeconomic consequences. It implies that widely estimated fossil generating costs understate their true risk-adjusted values by $50 \%$ and more.

Proper valuation of fossil fired generating projects has the effect of making renewables relatively more competitive than widely believed. However, the Oil-GDP relationship has still other consequences for the direct valuation of renewables. Both the macroeconomic (OilGDP effect) and the microeconomic (e.g. financial beta) evidence suggest that fossil prices rise during bad economic times - as they have done over the last three years - when GDP and other asset values are depressed. This in turn implies that renewables and other non-fossil generating alternatives provide counter-cyclical benefits - i.e. they are worth more when other assets are in decline (Lind, 1982).

So while the value of renewable generating assets clearly changes in response to fluctuating fossil prices, the changes are systematic, and highly desirable. Non-fossil generating assets are worth more when fossil prices are higher, which is correlated with periods of low economic activity and low asset values. This idea seems to have been first suggested by Robert Lind and Nobel Laureate J. Kenneth Arrow, who describe RE investments as a form of "national insurance" (Lind, 1982) that pays off during bad economic times. This hedge value of RE is a significant, but little recognized benefit of adding these technologies to the generating portfolio.

\footnotetext{
${ }^{6}$ A CAPM discount rate $=R_{f}+\beta(R P)$, where $R_{f}$ is the risk-free rate, and $R P$ is the market risk premium.

${ }^{7}$ Although the magnitude of the negative values varies over time (e.g. Bolinger et al., 2004), it is not uncommon to find fluctuating beta estimates even for widely published equity betas.

${ }^{8}$ Negative cash flow betas are not unusual. They imply that a cash flow stream, e.g. projected fossil fuel outlay, rises when other asset values are in decline. The Oil-GDP relationship makes this result expectational. On the other hand, negative equity betas - those estimated by stock analysts - are rare since they imply a financial asset that moves opposite to the rest of the market thereby forming a hedge. While few examples exist, gold share prices have exhibited this property from time to time, as have the shares of oil-exploration firms (Awerbuch, 1992).
} 


\section{Implications for energy diversity and security goals}

Security is a pre-eminent energy theme. There is no general agreement on how to define or measure it, although people instinctively recognize that maintaining portfolio diversity helps foster energy security. Diversity generally means a greater share of RE and other non-fossil sources. Security efforts often focus on how to cope with abrupt fossil supply disruptions. However, there exists a subtler and yet more powerful security idea: protecting against the risk of fossil fuel price increases (Awerbuch and Berger, 2003; see also Toman, 2002, Leiby, 2002). Energy security is reduced when countries (and individual firms) hold inefficient generating portfolios that are needlessly exposed to fossil risk. Efficient generating portfolios, on the other hand, minimize society's energy price risk.

People assume fossil prices are risky because they are difficult to predict, but this is only part of the story. As we have already suggested, fossil price volatility presents a special type of systematic risk that cannot be diversified. For national economies, the real risk of fossil price volatility is its negative impact on macroeconomic activity, through the Oil-GDP effect. The empirical literature we review in the next section suggests that oil price level changes and volatility imposes sizeable costs on the economies of oil consuming nations. Our view of energy security suggests that needless exposure to the Oil-GDP risk causes sizeable wealth and welfare losses. The value of such reduced security is more profound than traditional "energy security" concepts that focus on abrupt supply disruption.

Many people believe that RE-based electricity costs more. They therefore conclude that diversity must also cost more. They figure that when wind energy at $5 \mathrm{cent} / \mathrm{kWh}$ is added to a 3 -cent/kWh fossil generating mix, overall cost must rise. But talking about generating costs without also talking about financial risks created primarily by fuel price volatility is like watching a movie with the sound turned off: you miss a big part of the story. Adding RE technologies to a fossil portfolio may well raise overall weighted-average cost. But it also produces a second effect, equally important but widely ignored: it reduces risk (Awerbuch, $2004 a, b)$. The two effects will always combine to reduce expected generating costs. Greater renewables presence in the generating mix therefore enhances energy security while it reduces cost.

The next section surveys the empirical evidence in support of an Oil-GDP effect. To the extent they correlate negatively with economic indicators, future oil (and natural gas) price streams represent highly risky obligations for energy consumers. Every time oil (and natural gas) prices rise, economic activity - people's income and the value of their assets - declines by some measure. Capital market theory as well as common sense, tells us that a fluctuating future cost stream is risky. All the more so if it rises at times when economic activity and asset values are in decline. This adds an important dimension to fossil price risk and the idea of energy security and diversity. Subsequent sections evaluate the extent to which the OilGDP relationship further supports RE investments. 


\section{Oil Price Changes and Economic Activity - The Empirical Evidence}

This section provides a non-technical survey of the empirical Oil-GDP literature. ${ }^{9}$ While not exhaustive, our survey highlights the key developments, summarizes the major conclusions and provides the background and context for our subsequent estimate of the extent to which RE deployment might serve to mitigate the oil-GDP effects.

In addition to creating wealth transfers from oil importing to exporting economies, oil price changes affect macroeconomic activity in a number of ways. Oil price increases reduce production output and wages. They induce inflationary tendencies and raise interest rates, thereby reducing aggregate demand. Moreover, it is becoming increasingly clear that in addition to oil price levels, oil price volatility creates uncertainty that reduces wealth and stifles investment. Oil price changes do not affect all industries uniformly. Given capital and labour inflexibility, oil price changes alter the relative cost of goods and services, which shifts demand and raises unemployment in those sectors most affected. Monetary policy responses influence the macroeconomic impact of oil price shocks, at times worsening them, as subsequently discussed.

The study of oil price changes and their macroeconomic consequences seems to have its roots in the US, and is often traced to Hamilton's (1983) influential study which found that rising oil prices preceded seven of eight post-war US recessions (between 1948-1980). Oil price increases alone are not a necessary or sufficient condition for recessions. Expected inflation, monetary policy responses and the environment in which price changes occur also influence their GDP effects. While all of these factors play a role, the overwhelming weight of the evidence suggests that a $10 \%$ oil price increase induces GDP losses in the range of $0.5 \%$ to perhaps as much as $1.0 \%$ of GDP, for several quarters, or perhaps permanently. Hamilton's results essentially confirmed those of Darby (1982) and Bruno and Sachs (1982). The results were extended to other industrialized countries (Burbidge and Harrison, 1984) and were shown to have remained unchanged with the 1973 embargo (Gisser and Goodwin, 1986).

The oil price-GDP effect is not just a post-embargo innovation, but can be traced back to the 1940s. Hooker (1996) found that for the 1948-1972 pre-embargo period, a 10\% oil price rise reduces GDP by 0.6 percentage points. Post embargo, especially when the 1986 oil price collapse is included, the US Oil-GDP relationship appears even stronger (Mork, 1989).

The macroeconomic effects of oil price changes are not limited to the US, but have been measured in Greece, (Papapetrou, 2001) and by Mork et al. (1994) in Canada, Japan, West Germany, France, and the UK, although the effect did not hold in Norway, an oil exporter. While the effects vary from country to country, they are overall less dissimilar than expected, even for the oil exporting UK, where the GDP impact is similar to that of oil importing countries (Mork et al., 1994).

By the early 1990s, it was widely believed in the US that the new information economy and the dot-com explosion would serve to make the oil-GDP relationship obsolete. Tatom (1993),

\footnotetext{
${ }^{9}$ For additional details see Sauter and Awerbuch (2002), as well as the very useful technical reviews in Jones and Leiby (1996), Greene and Tishchishyna (2000) and Jones et al. (2004); Lovins et al. (2004) provide a broad quantitative and qualitative assessment of oil price impacts and categorize the literature by topical headings.
} 
however, found that the US's exposure to oil price changes remained unchanged in spite of the wide perception that the US economy had become less sensitive to oil.

The oil-GDP relationship is not limited to inflation and output effects. Rising oil prices affect stock markets (Jones and Kaul 1996) and are generally a predictor of stock returns in the postwar period. Oil price hikes had a "significant and detrimental" effect on the US stock market (1996, 471) because oil shocks raise costs and reduce earnings (Sadorsky, 1999; Papapetrou, 2001). Efficient financial markets therefore react with an immediate stock price decline (Sadorsky, 1999, 458).

One of the tricky questions surrounding the oil-GDP issue is how oil price changes can produce such dramatic results when oil accounts for only 3\% of GDP in the US. Rotemberg and Woodford (1996) and others tackled this question by excluding government activity, which is relatively unaffected by pricing and production decisions. They discovered that private output indeed declines following a positive oil price "innovation" so that a $1 \%$ oil price increase reduced output by $0.25 \%$ after five to seven quarters (Rotemberg and Woodford, 1996, 555). This equates to a $2.5 \%$ output reduction for a $10 \%$ oil price increase, nearly four times the Hooker (1996) result.

\section{Asymmetry in effects}

Symmetry in the oil - GDP relationship would imply that oil price decreases should stimulate GDP. Although rising oil prices reduced economic growth during the 1980s, the sharp 1986 price declines brought into question whether the Oil-GDP relationship might be asymmetric, implying that while price increases produce negative consequences, price decreases do not affect GDP. Mork (1989) separated oil price increases from decreases and found that increases influence economic growth while decreases have only very small effects, if any.

Other factors also contribute to asymmetry, e.g.: oil price increases are integrated more quickly in refined product prices than are price decreases (Huntington, 1998). ${ }^{\mathbf{1 0}}$ Mork et al., (1994), studying the US, Japan, Germany, France, UK, and Norway, found that oil price increases and decreases both produce negative economic impacts in the US and to a lesser extent in Germany and Canada, with ambiguous results for the other countries. Other studies (e.g. Lee et al., 1995) confirmed asymmetry for the US. Interestingly, although the US is less dependent on imported oil than other OECD countries, US price shocks seem to produce more powerful effects. Ferderer (1996) also suggests an asymmetric relationship arguing that positive oil price changes have twice as much influence on industrial production than do negative ones.

It seems that the traditional Oil-GDP relationship changed post-1986 and could no longer be described by a linear or even asymmetric model. However, asymmetric effects were evidenced in 1986 and in 1998, when sudden oil price declines were coupled with macroeconomic losses (Greene and Tishchishyna, 2000). A number of approaches have been taken to better understand the asymmetry puzzle, particularly in the US. These are described next.

\section{Monetary Policy as an Explanatory Factor for Asymmetry}

10 Price increases are passed through to consumers rather quickly, raising prices $1.4 \%$ in the first year and $2.2 \%$ in the second year (Huntington, 1998). 
Monetary and fiscal policy plays a role in the GDP effects that oil prices changes produce. Although monetary policy response is often immediate in an effort to prevent inflation, the response is not always symmetric after oil price decreases. Ferderer (1996), however, found a significant relationship between oil price increases and counter-inflationary responses. Nevertheless, he finds that price increases predict output, monetary policies notwithstanding. Potentially "asymmetric" monetary policy responses therefore, do not seem to fully explain the asymmetry of oil price shocks. Other evidence (Bernanke et al., 1997), suggests the opposite, i.e.: that recessions following the major shocks of 1973, 1979-80, and 1990 were caused by monetary policy, rather than the oil shock itself! Hamilton and Herrera (2004) reexamined the data and concluded that monetary policy could not have balanced the oil price shock impacts. They questioned whether monetary policy is sufficiently flexible in response to oil shocks. While it may possibly control inflation, could it quickly avert economic downturn? Indeed the more recent evidence (e.g. Balke et al., 2002) suggests monetary policy does not explain oil shock effects.

In general, policies that do not change expectations quickly or that cannot be expected to persist cannot offset the consequences of oil shocks in the short run (Tatom, 1993). Generally, the influence of oil shocks on employment between 1972 and 1988 was twice as important as the monetary policy responses (Davis and Haltiwanger, 2001). Merrill Lynch observes that the combined effects of oil price increases and monetary policy produce a Trifecta of Trouble that curbs GDP by an average of 2.5 percentage points the following year (CNN, 2004). Although the evidence is somewhat contradictory, "The division of responsibility" between monetary policy and oil price shocks for oil-price shock induced recessions, has "leaned heavily" toward the oil price shocks (Jones et al., 2004).

\section{The influence of oil price volatility}

Oil price movements from 1948-1985 generally took the form of price increases. This pattern abruptly changed with the 1986 price collapse, which initiated a series of large positive and negative price swings reflecting a substantial rise in oil price volatility, defined as the standard deviation of periodic changes. For example, world oil prices stood at $\$ 21.02$ in the first quarter of 1997. Two years later, by the first quarter of 1999 , it had dropped $50 \%$ to $\$ 10.86$, only to nearly triple again to $\$ 29.11$ by the third quarter of the following year (EIA, July 2002).

Given the increasing oil price volatility, the classical model and its focus on price level no longer sufficed. Lee et al. (1995) showed that Mork's (1989) classical model lost some of its statistical significance when applied to post-1988 data, an infirmity that could be remedied by an oil price "shock" variable which reflects surprise - the degree to which an oil price movement departs from the historic pattern. Sudden, strong oil price increases in a stable market produce more powerful GDP impacts.

A broader research emphasis, that now also reckoned with the effects of price volatility, began to confirm what many suspected intuitively, that volatility has a considerable influence on output. Volatile prices cause investment insecurity (Ferderer, 1996) and might underlie a 0.7 percentage point loss of US GDP growth between 1999 and 2001 (EIA, ibid.). This percentage translates to permanent GDP losses in the range of $\$ 75$ billion for each of those years. Oil price volatility is a major source of business cycle uncertainty and is "important" in 
explaining the performance of technology stocks (Sadorsky, 2003), widely believed to be unaffected by oil price movements.

Post-1986 oil price upturns were often immediately followed by even larger downturns, a condition observed by Hamilton (1996), who introduced the NOPI (net oil price increase) idea to evaluate the relative surprise of oil price movements by comparing current price with the maximum value observed during the preceding four quarters (Hamilton, 1996, 217). Applied to post-1986 data, NOPI shows that individual price increases generally represented simple corrections to earlier declines. In contrast to Hooker, Hamilton found that the oil-GDP relation remained statistically significant over a remarkably long period from 1948 to 1994, when viewed in terms of NOPI. For 1986 to 2001, the oil-GDP relationship is best explained by either a 3-year NOPI or Lee et al.'s (1995) shock variable (Hamilton, 2003).

Ferderer (1996), successfully separated the GDP effects of price level changes and volatility and found that both reduce output growth, although the effects occur over different time periods over the subsequent year. Oil price volatility explains $22 \%$ - and price level only $9 \%$ - of the error for 24-month industrial production forecasts, (Ferderer, 1996, 23) suggesting that volatility has more influence on growth. Hooker $(1996,205)$ confirmed these results.

Although the issue of volatility versus price level as drivers of GDP loss is not fully resolved, the significance of rising price volatility is becoming more widely accepted. Volatility increases uncertainty about future oil prices that lead companies to postpone irreversible investments. Volatility also disrupts labour markets. The oil-GDP relationship seems to be non-linear and possibly asymmetric so that price increases matter "substantially more" than decreases and the economy's sensitivity to price changes seems to be dampened by previous volatility (Hamilton, 2000, 25). While there is insufficient historic information to demonstrate that one functional form is an unambiguously better predictor of GDP growth than the other (Hamilton, 2000, 34), nonlinear representations (e.g. Lee et al., 1995 and Hamilton, 1996) do seem superior.

\section{Asymmetry - Concluding Ideas}

One of the major remaining questions concerning the oil-GDP relationship is its "apparent" asymmetry (Finn, 2000, 415). The idea that the oil price-GDP relationship is asymmetric may have relevance to our point, which is that RE investments, which reduce the price of gas, and in turn oil, will help avoid macroeconomic losses produced by the traditional oil-GDP relationship. Although this outcome may be more limited if one believes that the oil-GDP relationship is asymmetric, Leiby (2004) uses precisely this approach to argue for the benefits of expanding the SPR (Strategic Petroleum Reserve).

While several researchers find that the Oil-GDP relationship has been asymmetric since the mid 1980s, their conclusions are strongly contested by Tatom (1993), who argues convincingly that if price decreases create little economic stimulus as asymmetry proponents suggest, then an oil price rise which is later fully reversed will leave net effects that are not neutral, but that closely resemble the effects of the initial price increase (Tatom, 1993, 11). This proposition is indeed difficult to accept. The problem may well lie with the fact that 
some of the asymmetry proponents do not control for the effect of exogenous policies such as the US 1986 Tax Reform Act, which reduced business investment. It is therefore quite likely that the "failure of these studies to find symmetric effects" on US output arises from the substantial negative influences of the 1986 tax change (Tatom, 1993).

Persistent oil price reductions, e.g. those produced by permanent demand reductions, could have positive macroeconomic effects. Demand dislocation may however offset these positive effects (Mory, 1993). Increased RE deployments could serve to reduce expected oil prices and volatility, thereby producing positive GDP impacts. Our analysis involves RES-E investments that reduce gas and oil prices. The effects we measure are based on avoided oil price increases, thus reducing the importance of the asymmetry issue. Following Leiby (2004), therefore, we express our results in terms of avoided GDP losses.

\section{Oil-GDP Implications for Renewables}

The empirical evidence surveyed in the previous section clearly suggests that oil price increases produce significant macroeconomic losses in oil consuming as well as oil exporting countries. The oil-GDP relationship has wide ranging implications for a variety of issues related to energy security (Awerbuch, 2004a), the benefit of increasing the Strategic Petroleum Reserve (Leiby, 2004), and, as discussed in an earlier section, the appropriate CAPM-based techniques for estimating electricity generating costs.

We suggest however, that there exists another set of implications, largely unrecognized, that could profoundly affect how we value the additional public and private investments required to commercialize and further deploy renewable technologies. In this section we suggest that renewables investments can help mitigate the economic losses produced by the oilGDP effect. We explore whether renewables can actually mitigate these OilGDP losses to a sufficient degree so as to release at least a reasonable share of the funding required for their own further deployment. If this were to be the case, then it could be argued that at least a portion of the outlays for RE investment would be directly offset by the release of economic wealth from avoided Oil-GDP losses.

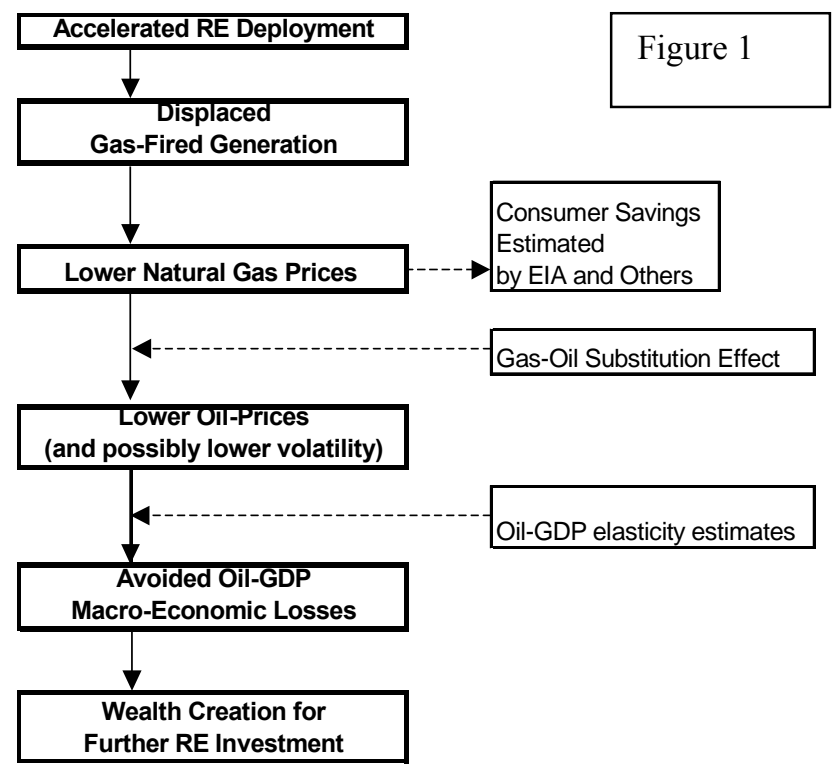

The empirical evidence of the previous section clearly implies that such losses are real, and that their avoidance will create Further RE Investment real wealth gains worldwide. To the extent this wealth creation may be more speculative or abstract or future-oriented, however, it may not have the same political weight as a set of current cash outlays for RE. Quite plainly, it will never be possible to demonstrate with absolute certainty that by avoiding some share of oil outlays in a given year, we might avert a given magnitude of GDP losses. Such a demonstration cannot be made because such an 
experiment can never be constructed. Nonetheless, it is essential for policymakers to understand that the weight of the statistical evidence suggests this to be the case.

In the remainder of this section we demonstrate that the deployment of RE can release substantial wealth that is now lost to the Oil-GDP effect, thereby helping to fund further RE investments. We argue that increasing the RE share in the generating mix will serve to avoid economic losses induced by the Oil-GDP relationship. We posit that this happens though a straightforward set of drivers (Figure 1). First, increased RE penetration reduces demand for gas, which reduces natural gas prices. A number of studies have recently estimated the magnitude of this effect for the US as part of the American debate over a national renewables portfolio standard (RPS). Lower gas prices in turn put pressure on oil prices, to the extent that gas and residual oil are substitutes in a variety of industrial heating, co-firing and other applications (e.g. Brown, 2003). Finally, the downward pressure on oil prices helps avoid GDP losses by mitigating the consequences of the Oil-GDP effect. The linkages in Figure 1 can be summarized as:

\section{Avoided GDP Losses $=(\%$ Oil Price Change $) \times($ GDP Elasticity $) \times$ GDP}

We discuss each of these coefficients, beginning with the percent change in oil price, which is based on recent estimates of the extent to which RE deployment shifts demand for natural gas and lowers its price. The effect represents a shift in demand, not a move along the demandcurve as further discussed subsequently.

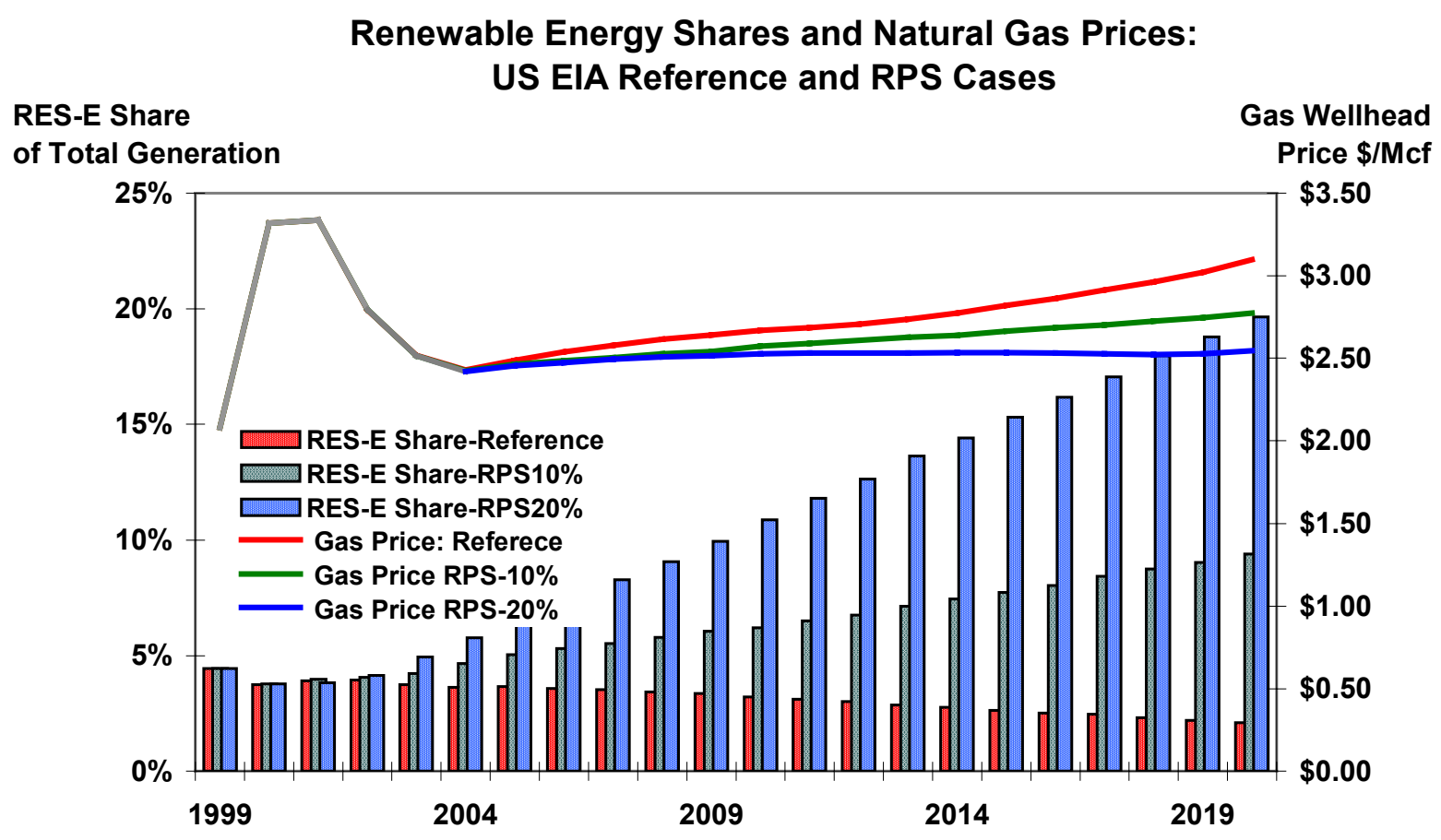

Figure 2 (Based on UCS, 2002b) 


\section{The Impact of RE Deployment on Natural Gas and Oil Prices}

The US-EIA and others estimate that additional RE shares in the US generating mix will displace natural gas and hence reduce natural gas prices. These studies generally estimate the effects of a nominal $10 \%$ or $20 \%$ RPS. Figure 2 illustrates the yearly estimates produced by one of the studies (UCS, 2002b) in our sample. It shows the yearly RES-E additions over the reference case for $10 \%$ and $20 \%$ RPS targets and the estimated gas prices reductions.

The gas price reductions estimated in these studies represents a shift in demand for natural gas induced by the substitution of renewables for gas-fired generation. This differs from reduced consumption along the existing natural gas demand-curve, a move that could only occur at a higher price. The idea that deploying RE lowers gas prices also makes sense from a cost or supply point of view. If the gas demand curve shifts to the left, (i.e. less quantity is demanded) the cost of delivered gas will decline as marginal costs are reduced - in other words, as more expensive gas fields and delivery modes are shut down. ${ }^{12}$

The full sample of studies is summarized in Table 1, which estimates oil price reduction based on estimated gas displacement rates coupled with long-term gas-oil correlation rates. ${ }^{13}$ On average, a $5.1 \%$ RES-E increase over the reference case reduces gas prices by $4.2 \%$, which implies an $8.2 \%$ gas price reduction for a $10 \%$ RES-E increase. This, in turn, yields a $6.2 \%$ oil price decrease, a figure that is applied in Table 5 (Panel I) to calculate avoided GDP losses.

\begin{tabular}{|c|c|c|c|c|c|}
\hline \multicolumn{6}{|c|}{$\begin{array}{l}\text { Table 1: } \\
\text { Additional RES-E Deployment: Estimated Gas and Oil Displacement and Price Effects }\end{array}$} \\
\hline \multirow[b]{3}{*}{ Reference Study } & \multirow{3}{*}{$\begin{array}{l}\text { RES-E } \\
\text { Additions } \\
\text { Over } \\
\text { Reference } \\
\text { Case }\end{array}$} & \multirow{2}{*}{\multicolumn{2}{|c|}{$\begin{array}{l}\text { Estimated Natural Gas Price } \\
\text { Reduction }\end{array}$}} & \multirow{2}{*}{\multicolumn{2}{|c|}{$\begin{array}{l}\text { Resulting Oil Price Reductions } \\
\text { Long-term Gas-Oil Correlation } \\
(\rho=0.75)\end{array}$}} \\
\hline & & & & & \\
\hline & & Percent & $\begin{array}{l}\text { Per } 10 \% \\
\text { RES-E } \\
\text { Increase }\end{array}$ & Percent & $\begin{array}{l}\text { Per } 10 \% \\
\text { RES-E } \\
\text { Increase }\end{array}$ \\
\hline \multicolumn{6}{|l|}{ Union of Concerned Scientists } \\
\hline Feb $200210 \%$ RPS & $4.0 \%$ & $-4.7 \%$ & $-11.3 \%$ & $-3.5 \%$ & $-8.5 \%$ \\
\hline Feb $200220 \%$ RPS & $9.2 \%$ & $-7.4 \%$ & $-6.9 \%$ & $-5.6 \%$ & $-5.2 \%$ \\
\hline Sep 2002 10\% RPS & $1.6 \%$ & $-1.4 \%$ & $-10.3 \%$ & $-1.0 \%$ & $-7.7 \%$ \\
\hline March 2004 10\% RPS & $1.9 \%$ & $-1.2 \%$ & $-5.7 \%$ & $-0.9 \%$ & $-4.5 \%$ \\
\hline March 2004 20\% RPS & $7.3 \%$ & $-2.7 \%$ & $-3.7 \%$ & $-2.0 \%$ & $-2.8 \%$ \\
\hline Sep 2004 10\% RPS & $3.3 \%$ & $-1.1 \%$ & $-3.2 \%$ & $-0.8 \%$ & $-2.7 \%$ \\
\hline Sep $200420 \%$ RPS & $7.4 \%$ & $-3.2 \%$ & $-3.7 \%$ & $-2.4 \%$ & $-2.8 \%$ \\
\hline \multicolumn{6}{|l|}{$\begin{array}{l}\text { US-Energy Information } \\
\text { Administration }\end{array}$} \\
\hline $\begin{array}{l}200110 \% \text { RPS (incl hydro) } \\
200120 \% \text { RPS (incl hydro) }\end{array}$ & $\begin{array}{r}4.4 \% \\
12.0 \%\end{array}$ & $\begin{array}{l}-5.2 \% \\
-12.5 \%\end{array}$ & $\begin{array}{l}-11.5 \% \\
-106 \%\end{array}$ & $\begin{array}{l}-3.9 \% \\
-9.4 \%\end{array}$ & $\begin{array}{l}-8.7 \% \\
-7.9 \%\end{array}$ \\
\hline $200210 \%$ RPS & $2.9 \%$ & $-3.0 \%$ & $-10.1 \%$ & $-2.2 \%$ & $-7.6 \%$ \\
\hline 2002 10\% RPS (high) & $4.3 \%$ & $-4.9 \%$ & $-13.6 \%$ & $-3.7 \%$ & $-10.2 \%$ \\
\hline $200220 \%$ RPS & $5.9 \%$ & $-6.5 \%$ & $-11.4 \%$ & $-4.9 \%$ & $-8.5 \%$ \\
\hline $200310 \%$ RPS & $1.7 \%$ & $-0.5 \%$ & $-3.9 \%$ & $-0.4 \%$ & $-2.9 \%$ \\
\hline Averages & $5.1 \%$ & $-4.2 \%$ & $-8.2 \%$ & & $-6.2 \%$ \\
\hline
\end{tabular}

12 Wiser et al. (2004) give a graphic microeconomic analysis of this shift.

13 Given considerable year-to-year differences we apply the average of the yearly estimates in each study. Wiser et al. (2004) also average the yearly results but produce a set of inverse price elasticities that may differ from our annual impulse effects. 


\section{Gas-Oil Links}

Long-term oil-gas correlations for the US and EU are quite high - in the range of 0.70 for the 1973-2003 and even higher for more recent periods (Table 2). Brown (2003) concludes that oil and natural gas prices have tracked each other over long periods because gas and oil are substitutes in industrial applications. $^{14}$ Figure 2 illustrates this co-movement in both the US and the EU. Increased fuel-switching capability will likely continue

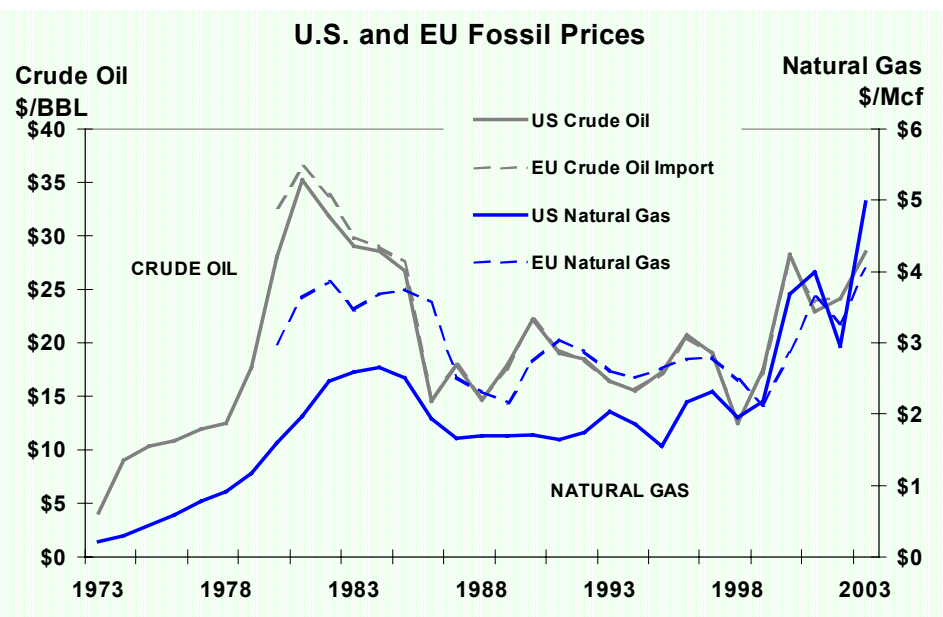

Figure 3: US and EU Fossil Prices into the future, thereby continuing high gas-oil correlations that have recently again "tightened" (Business Journals, 2004) as illustrated in Table 2. As a result of oil-gas substitution, lower natural gas prices will tend to push oil prices down (Brown, 2003; Brown and Yücel, 2002). The long-term gas-oil correlations provide the basis for one of the avoided GDP loss estimates (Table 5, Panel 1) as discussed later.

Table 5 also shows a set of avoided GDP loss estimates that do not rely on a gas-to-oil link but instead are based on an estimated gas-GDP effect. The GDP consequences of natural gas prices movements have not been widely studied, although Brown (2003) presents some estimates for the US. Measured oil price shock effects may actually represent the "combined effects" of oil and gas price changes (ibid.) and a "rough approximation" of a natural-gas shock effect might be about $40 \%$ of an oil shock effect. ${ }^{15}$

\begin{tabular}{|c|c|c|}
\hline \multicolumn{3}{|c|}{ Table 2} \\
\hline \multicolumn{3}{|c|}{ Oil - Gas Price Correlations } \\
\hline Period & US ${ }^{a} /$ & EU $\underline{b} /$ \\
\hline $1973-2003$ & 0.70 & $0.71 \mathrm{c}^{\mathrm{c}}$ \\
\hline $1990-2003$ & 0.79 & 0.76 \\
\hline 1997-2003 & 0.86 & 0.75 \\
\hline \multicolumn{3}{|c|}{$\begin{array}{l}\text { a/ EIA, Monthly Energy Review, Sep 2004; } \\
\text { b/ IEA, Average Crude Oil Import Costs, Aug, } \\
\text { 2004; Natutral Gas Information Book, } 2004 \\
\text { c/ 1980-2003 }\end{array}$} \\
\hline
\end{tabular}

14 Brown (2003) finds that as a result of strong US demand for gas, the historic gas-oil price rule, i.e. Henry Hub gas price per mmBtu approximates one-tenth the per/barrel price of West Texas Intermediate, may have been recently exceeded.

15 This yields a US GDP loss of $0.6 \%-2.1 \%$. 


\section{Oil-GDP Elasticity Estimates}

RE deployment displaces gas-based generation, which reduces natural gas prices. This puts downward pressure on oil prices through the substitution effect as discussed in the last section and mitigates costly Oil-GDP losses. This section summarizes the empirical GDP elasticity estimates, defined as the percentage change in GDP relative to the percentage oil price change. Recent OilGDP elasticity estimates for various countries (Table 3 ) range from a high of 9.8\% in France (a doubling in oil price reduces GDP 9.8\%) to $2.4 \%$ in Greece.

\begin{tabular}{|c|c|c|c|}
\hline \multicolumn{2}{|c|}{ Oil Importers } & \multicolumn{2}{|c|}{ Oil Exporters } \\
\hline Country & $\begin{array}{c}\text { GDP } \\
\text { Elasticity }{ }^{a}\end{array}$ & Country & $\begin{array}{c}\text { GDP } \\
\text { Elasticity }{ }^{a}\end{array}$ \\
\hline $\begin{array}{r}\text { Taiwan } \\
\text { Hong Kong }\end{array}$ & $\begin{array}{l}-8.4 \% \\
-6.5 \%\end{array}$ & $\begin{array}{r}\text { Indonesia } \\
\text { Malavsia }\end{array}$ & $\begin{array}{l}-4.3 \% \\
-5.6 \%\end{array}$ \\
\hline Japan & $-5.8 \%$ & Norway & $5.1 \%$ \\
\hline South Korea & $-8.7 \%$ & & \\
\hline Philippines & $-3.6 \% \frac{\mathbf{b} /}{-}$ & & \\
\hline Singapore & $-4.2 \%$ & & \\
\hline Thailand & $-8.4 \%$ & & \\
\hline France & $-9.8 \%$ & & \\
\hline Germany & $-8.1 \%$ & & \\
\hline Greece & $-2.4 \%$ & & \\
\hline U.K. & $-3.8 \%$ & & \\
\hline Average & $-6.3 \%$ & Average & $-1.6 \%$ \\
\hline $\begin{array}{l}\text { a. GDP chang } \\
\text { b. Statistically }\end{array}$ & $\begin{array}{l}\text { for Oil-Price } \\
\text { nsignificant }\end{array}$ & & \\
\hline
\end{tabular}

Our review of recent studies (Table 4) suggests an average Oil-GDP elasticity of $7.3 \%$, which compares to a $6.4 \%$ figure reported by Jones et al. (2004), and a 4.9\% average reported 10 years earlier by Mory (1993).

Table 4: Summary of Estimated GDP Elasticities

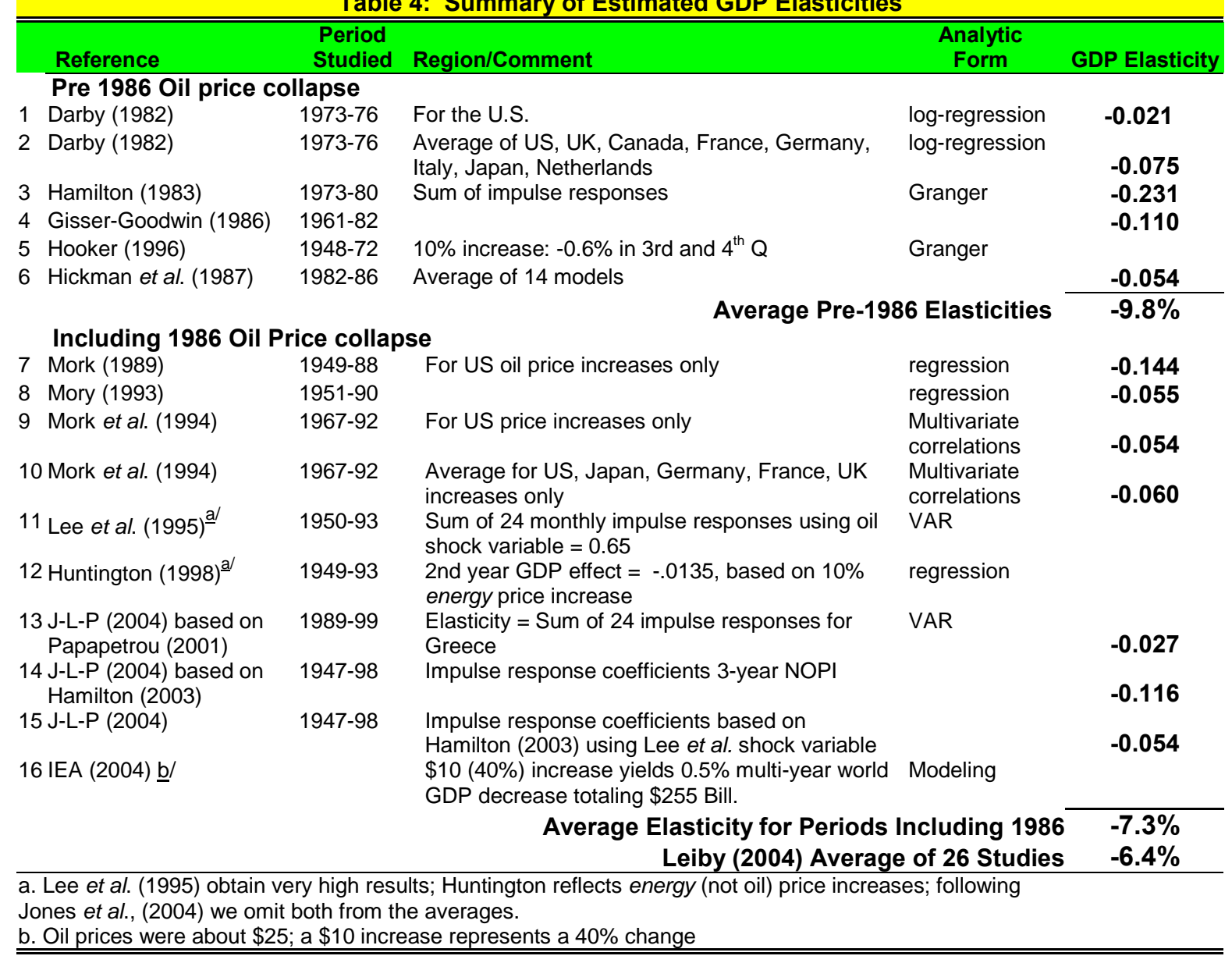


The GDP effect of an assumed $10 \%$ oil price increase can now be estimated using the average $7.3 \%$ elasticity estimate of Table 4 and the US (or EU) 2003 GDP of about $\$ 11,000$ billion:

$$
\begin{aligned}
\text { Avoided GDP Loss } & =\% \text { OilPriceChange } \times \text { GDP Elasticity } \\
& =10 \% \text { GDP } \\
& =\$ 80.3 \text { billion }
\end{aligned}
$$

A $10 \%$ oil price increase produces GDP losses in the range of $\$ 80$ billion in the EU and the US.

We are interested, however, in the Oil-GDP consequences of increased RE deployment. In the next sub-section we present a range of estimates, which we then compare to the EREC and G8 estimates of required RE investments to meet $\mathrm{EU}$ and other

\begin{tabular}{|c|c|}
\hline \multicolumn{2}{|c|}{ Gross Domestic Product } \\
\hline Region & $\begin{array}{c}\text { GDP } \\
\text { (USD \$Bill.) }\end{array}$ \\
\hline U.S. & $\$ 10,882$ \\
\hline EU-25 & $\$ 10,970$ \\
\hline OECD & $\$ 18,659$ \\
\hline World & $\$ 36,356$ \\
\hline
\end{tabular}
targets. In general, we find that RE investments produce GDP loss mitigations equalling at least $30 \%$ of their own value.

Source: World Bank, World Development Indicators Database, Sep-2004

\section{Avoided Oil-GDP Losses as Offsets for RE Investments}

Table 5 gives the estimated avoided permanent GDP losses for a $10 \%$ increase in RE deployment in the US, the EU-15, ${ }^{16}$ the OECD and the world. These estimates are based on the range of values for GDP elasticity and oil price reductions discussed in the previous two

\begin{tabular}{|c|c|c|c|c|c|c|c|}
\hline \multicolumn{8}{|c|}{$\begin{array}{l}\text { Table 5: } \\
\text { Avoided GDP Losses for 10\% RE Addition a/ }\end{array}$} \\
\hline \multirow[b]{2}{*}{ GDP Elasticity Measure } & \multicolumn{3}{|c|}{ Avoided Loss Estimation } & \multicolumn{4}{|c|}{$\begin{array}{l}\text { Avoided GDP Losses } \\
\text { (USD \$billions) }\end{array}$} \\
\hline & $\begin{array}{c}\text { GDP } \\
\text { Elasticity }\end{array}$ & $\begin{array}{l}\text { Oil Price } \\
\text { Reduction }\end{array}$ & $\begin{array}{l}\text { Avoided } \\
\text { GDP Loss }\end{array}$ & US & EU-15 & OECD & World \\
\hline \multicolumn{8}{|c|}{ PANEL I: Long Term Oil-Gas Correlation } \\
\hline $\begin{array}{r}\text { Pre-1986 Average } \\
1986 \text { Inclusive Average } \\
\text { Leiby (2004) Average }\end{array}$ & $\begin{array}{l}-9.8 \% \\
-7.3 \% \\
-6.4 \%\end{array}$ & $\begin{array}{l}-6.2 \% \\
-6.2 \% \\
-6.2 \%\end{array}$ & $\begin{array}{l}0.60 \% \\
0.45 \% \\
0.39 \% \\
\quad \text { Averages }\end{array}$ & $\begin{array}{l}\$ 66 \\
\$ 49 \\
\$ 43 \\
\$ 53\end{array}$ & $\begin{array}{l}\$ 67 \\
\$ 49 \\
\$ 43 \\
\$ 53\end{array}$ & $\begin{array}{l}\$ 113 \\
\$ 84 \\
\$ 74 \\
\$ 90\end{array}$ & $\begin{array}{l}\$ 221 \\
\$ 164 \\
\$ 144 \\
\$ 176\end{array}$ \\
\hline \multicolumn{8}{|c|}{ PANEL II: Using Gas-Only GDP Elasticity } \\
\hline $\begin{array}{r}\text { Pre-1986 Average } \\
1986 \text { Inclusive Average } \\
\text { Leiby (2004) Average }\end{array}$ & $\begin{array}{c}\begin{array}{c}\text { Gas-only } \\
\text { Elasticity }\end{array} \\
-3.9 \% \\
-2.9 \% \\
-2.6 \%\end{array}$ & $\begin{array}{c}\text { Gas Price } \\
\text { Reduction } \\
-8.4 \% \\
-8.4 \% \\
-8.4 \%\end{array}$ & $\begin{array}{c}\begin{array}{c}\text { Avoided } \\
\text { GDP Loss }\end{array} \\
0.33 \% \\
0.24 \% \\
0.21 \% \\
\text { Averages }\end{array}$ & $\begin{array}{l}\$ 36 \\
\$ 27 \\
\$ 23 \\
\$ 29\end{array}$ & $\begin{array}{l}\$ 36 \\
\$ 27 \\
\$ 23 \\
\$ 29\end{array}$ & $\begin{array}{l}\$ 61 \\
\$ 45 \\
\$ 40 \\
\$ 49\end{array}$ & $\begin{array}{l}\$ 119 \\
\$ 89 \\
\$ 78 \\
\$ 95\end{array}$ \\
\hline $\begin{array}{l}\text { a. Based on US-EIA RES-E ta } \\
\text { b. } 40 \% \text { of Oil-GDP elasticity }\end{array}$ & ggets & & Overall Average & $\$ 41$ & $\$ 41$ & $\$ 70$ & $\$ 136$ \\
\hline
\end{tabular}
sub-sections. The results are reasonable to the extent that gas displacement rates are similar to those estimated for the US (see Table 1).

Table 5 shows calculations for two assumed gas-oil substitution price effects. Panel I is based on the long-term gas-oil correlation, taken as 0.75 , which yields an average $6.2 \%$ oil price reduction in response to a 10\% RE deployment (see Table 1). Panel II gives a second set of oil price reduction estimates based on the gas-only elasticities discussed previously.

${ }^{16}$ We use EU-15 data for subsequent comparison with other estimates. 
The Avoided GDP Losses in Panel I suggest that if the oil-gas price co-movements of the last 30 years continue, a 10\% increase in RE deployment produces avoided GDP losses ranging from about $\$ 43$ billion to about \$66 billion for the US and the EU, \$74-113 billion for the OECD and \$144- \$221 billion globally. The average estimate for the four regions is \$53 billion for the US, and EU, $\$ 90$ billion for the OECD and $\$ 176$ billion for the world economy.

Panel II uses the direct gas-only GDP effect suggested by Brown (2003), which yields a set of avoided GDP losses in response to a 10\% RE deployment that average about \$29 billion for the US and EU, \$49 billion for the OECD and \$95 billion globally.

\section{$\underline{\text { EU and OECD Renewable Electricity Targets }}$}

These avoided loss estimates are sizeable relative to projected investment requirements for additional RE deployment in the OECD and Europe. An IEA-led G8 Task Force estimated a 10 -year public investment in OECD countries of approximately USD \$90-\$120 billion to achieve an $8.6 \%$ RES-E share. ${ }^{17}$ This range, which averages $\$ 105$ billion, converts to $\$ 159$ billion for a $10 \%$ RE share (Table 6), which compares to $\$ 49-\$ 90$ billion in avoided GDP losses ( $\$ 70$ billion average) shown for the OECD in Table 5. The analysis therefore suggests that $43 \%$ of the projected G8 outlay for RES-E is offset by avoided GDP losses. ${ }^{18}$

\begin{tabular}{|c|c|c|c|c|c|c|c|c|}
\hline \multicolumn{9}{|c|}{$\begin{array}{c}\text { Table } 6 \\
\begin{array}{c}\text { Summary of Estimated RE Investment Requirements } \\
\text { and Avoided GDP Offsets }\end{array} \\
\end{array}$} \\
\hline \multirow{3}{*}{$\begin{array}{l}\text { Source } \\
\text { G8 } \\
\text { (OECD) }\end{array}$} & \multirow{3}{*}{$\begin{array}{c}\text { Nominal } \\
\text { Target } \\
\\
\\
\mathbf{8 . 6 \%} \\
1997-2010 \\
\end{array}$} & \multicolumn{2}{|c|}{$\begin{array}{c}\text { Res-E } \\
\text { Additions }\end{array}$} & \multirow{2}{*}{$\begin{array}{c}\begin{array}{c}\text { Projected } \\
\text { Outlay }^{\text {al }}\end{array} \\
\text { Billions } \\
\end{array}$} & \multicolumn{2}{|c|}{$\begin{array}{l}\text { Outlay for } 10 \% \\
\text { RES-E Addition }\end{array}$} & \multicolumn{2}{|c|}{$\begin{array}{l}\text { Average } \\
\text { GDP Offset }\end{array}$} \\
\hline & & TW & $\%$ & & $\begin{array}{l}\text { Billion } \\
\text { Euros }\end{array}$ & $\begin{array}{c}\text { Billion } \\
\text { USD }\end{array}$ & $\begin{array}{c}\text { Billion } \\
\text { USD }\end{array}$ & $\%$ \\
\hline & & 170 & $6.6 \%$ & $\$ 105$ & - & $\$ 159$ & $\$ 70$ & $43 \%$ \\
\hline \multirow{2}{*}{$\begin{array}{c}\text { EREC/ } \\
\text { EWEA } \\
\text { (EU-15) }\end{array}$} & $\begin{array}{c}12 \% \\
2001-10\end{array}$ & 287 & $7.2 \%$ & $€ 62$ & $€ 86$ & $\$ 108$ & $\$ 41$ & $38 \%$ \\
\hline & $\begin{array}{c}\mathbf{2 0} \% \\
2001-20 \\
\end{array}$ & 778 & $19.0 \%$ & $€ 197$ & $€ 103$ & $\$ 129$ & $\$ 41$ & $32 \%$ \\
\hline
\end{tabular}

The European Renewable Energy Council, (EREC, 2004) also projects RE deployment needs and cost for the EU-15 2010 and 2020 targets. ${ }^{19}$ We reduced these outlays by $44 \%$ in order to

17 Electricity capacity in developed countries exceeds 1.8 million MW, of which 40,000 MW (2\%) is renewable. The World Energy Outlook 2000 (IEA, 2000) projects that OECD countries could increase their renewables generating share to $8.6 \%$ by 2010 (590 TWh), which the G8 estimates would require 160,000 to $180,000 \mathrm{MW}$ of renewables (excluding large hydro), representing capital investments of US $\$ 90-\$ 120$ billion. This averages $\$ 105$ billion and, by our reckoning, $\$ 560-\$ 660$ per $\mathrm{kW}$.

18 This offset may be a bit high, although the G8's assumed deployment costs - about $\$ 600 / \mathrm{kW}$ may be optimistic. Also, OECD gas displacement rates may be lower than the US rates we use.

19 EREC's numbers refer to investments for all renewables needed to reach the EU-15 targets of 12\% by $2010,20 \%$ by 2020 . It estimates that to meet total EU-15 targets of $12 \%$ and $20 \%$, RE shares would have to increase from $15.1 \%$ in 2000 to $22 \%$ in 2010 and $34 \%$ in 2020 (EREC, 2004). The associated investment costs are $€ 140$ billion for 2001-2010 and $€ 303$ billion for 2011-2020, which yields $€ 443$ billion for the 2001-2020 period. This includes the costs of all renewables for other than electricity generation. We reduce these outlays by $44 \%$ to account for outlays for non-generation renewables. 
remove investments associated with heat and other non-generating uses of renewables and estimate the EREC required investment for RES-E additions at $€ 62$ billion for the $12 \%$ target, which involves a 7.2\% RES-E addition (Table 6). We adjust this value to yield $€ 103$ billion, the required outlay for a 10\% RES-E addition $(€ 62 \times 10 \% / 7.2 \%=€ 86$ billion). Based on the Table 5 results, this investment would be offset by average avoided GDP losses averaging $\$ 41$ billion or $38 \%$ of the projected outlays. EREC's 2020 investment projections require an electricity-only investment of $€ 197$ billion (Table 6), which produces an offset estimate of $32 \%$.

The analysis of this section, using G8 and EREC projections, therefore suggests that $32 \%-$ $43 \%$ of future EU and OECD outlays for renewables electricity may be offset by avoided macroeconomic losses induced by the GDP-oil effect.

\section{$\underline{\text { Additional Issues }}$}

All our estimates ignore timing differences between outlays and avoided losses. Moreover since RE investments are not made lump-sum, but rather are stretched out over a decade or two, these comparisons further assume that the annual "impulse effects" (Jones et al., 2004) of the RE investment streams can reasonably be reflected by a single total GDP elasticity effect. By not explicitly dealing with each annual change, we may underestimate the full effect.

Finally, we treat avoided Oil-GDP losses as a one-time effect (per Jones et al., 2004) thereby ignoring the possibility that a lower demand for oil may produce a perpetuity of annual impulse effects whose societal present value may greatly exceed its one-time elasticity effect. To illustrate, a perpetual $\$ 10$ billion benefits stream, valued at a $2 \%$ societal discount rate, produces a sizeable present value of $\$ 10 / 0.02=\$ 500$ billion. We leave these issues for further research, and conclude that even if GDP loss is treated as a one-time effect, at least a significant portion of RE investment seems to be offset by avoided economic losses. Assuming that our estimates are reasonably correct, this creates a sizeable externality for RE and other non-fossil sources that has to date been entirely ignored.

Every MW of energy efficiency and non-fossil generating technology thus creates a GDP externality by helping society avoid oil-induced macro-economic losses. Investors cannot recoup the full measure of this effect, which accrues to all members of society. As a consequence they may under-invest in these technologies, a situation that could be remedied with tax credits or certificate trading programs. Although detailed KW-based GDP loss estimates are beyond our present scope, we roughly estimate that on average, a $\mathrm{KW}$ of nonfossil generating technology potentially avoids \$250-\$450 in GDP losses. ${ }^{20}$ This is not spread uniformly across technologies, and we further estimate that the offset is worth about $\$ 200 / \mathrm{kW}$ for wind and solar (23\% capacity factor) and almost $\$ 800 / \mathrm{kW}$ for geothermal, biomass and nuclear ( $92 \%$ capacity factor). The societal valuation of non-fossil alternatives needs to reflect these avoided GDP loss values since they create a benefit not fully captured by private investors.

20 These figures are developed from projected generation additions. Similar calculation using EIA projected capacity figures yields an average range of $\$ 400-\$ 800$ per KW of renewables. 


\section{Conclusions}

This paper discusses three important energy policy issues related to the Oil-GDP relationship: i) its direct effects on the proper estimation of generating costs for renewable and conventional technologies; ii) its consequences for a set of reconceptualized energy security and diversity objectives, and finally, iii) its effect on the societal valuation of renewables to the extent that RE investments may displace gas and oil thereby reducing their market price and volatility, which in turn helps avoid Oil-GDP driven economic losses.

\section{Microeconomic and Finance Implications of the Oil-GDP Relationship}

The macroeconomic Oil-GDP relationship has a microeconomic analogue. Future fossil price streams - e.g. future gas outlays for electricity generation, show a negative beta, the standard finance covariance risk measure. This implies that they are systematically risky, which is another way of saying that fossil price fluctuations are not random, but are statistically high when GDP growth and the value of other assets are low.

This has several implications. First, it implies that traditional electricity generating cost estimates significantly understate the true economic cost of fossil-based generation. Financeoriented, risk-adjusted estimates suggest that the cost of gas-fired generation is at least $50 \%$ higher than widely believed. Further, the negative beta estimates imply that fossil fuel price spikes have a double whammy effect for consumers. They not only drive up the cost of everything from driving to switching on the lights, but they also produce measurable declines in consumers' wealth - higher energy prices eventually lower their incomes and the value of their homes and other assets. Finally, the negative Oil-GDP relationship implies the need for new energy security concepts that stress the design of optimal generating portfolios that avoid needless exposure to fossil price risk.

As a matter of urgency, policy makers must understand that one of the principal implications of the negative Oil-GDP relationship is that traditional fossil-based electricity cost estimates are significantly understated relative to renewables and other non-fossil technologies.

\section{Societal Valuation: Renewables Investment Costs and the Oil-GDP Relationship}

In addition to the microeconomic consequences of the oil-GDP effect, it is equally important that policy makers understand the impact of fossil price movements on national economies. We suggest that such Oil-GDP induced losses can be significantly reduced through investments in renewable energy and other non-fossil alternatives.

We present a range of estimates. At upper end, these produce surprisingly high benefit measures that almost suggest that RE investing is the financial equivalent of a perpetual motion machine ${ }^{21}$ in the sense that the greater the RE deployment, the more GDP loss is avoided through the Oil-GDP effect. Indeed, if avoided macroeconomic losses we estimate

21 Brealey and Myers (1995) refer to this as a "money machine." 
can be interpreted as perpetual benefit streams, then our upper-range estimates imply that desired world RES-E target attainment can be virtually levitated on the back of an exploited oil-GDP relationship.

Experience suggests that such powerful relationships, if they occur in an economy, do not last indefinitely. We would therefore guess that as RE is deployed in substantial quantities, so that significant shares of natural gas and oil are displaced, Oil-GDP elasticities would become smaller thereby diminishing the effect over time. This issue deserves further attention. In the meantime, we feel reasonably confident that we can expect the GDP elasticities and other technical coefficients we applied to remain relatively stable over the fairly small range we examined. This range, which covers expected 10\%-20\% RES-E deployments, potentially reduces gas and oil prices by less than $10 \%$, which in turn avoids GDP losses in the order of $0.6 \%$, or about $\$ 30-\$ 50$ billion in the US and EU and \$50-\$90 billion for the OECD. These conclusions, which we believe are amply supported by the empirical literature, suggest that one-third or more of renewables investments in these regions may be offset by avoided GDP losses.

Empirical evidence on the Oil-GDP effect has been developing over the last 25 years, in some three dozen or more studies, conducted in both western and eastern countries by academic and other research organizations, NGOs, as well as multi-lateral entities. This evidence convincingly suggests that rising oil prices and their volatility produce negative macroeconomic consequences including reduced output and employment, increased inflation, and a loss to financial and other assets. The negative Oil-GDP relationship is by now widely accepted, although questions remain. For example, oil price increases are usually accompanied by monetary policy responses that can exacerbate the effects. The weight of the evidence however suggests that while monetary policy plays a role, the "division of responsibility, between monetary policy and price shocks," as Jones et al. (2004) put it, has leaned heavily toward the latter.

Given the political realities, our findings, though reasonable and sound, may not provide a sufficient platform for policy making. Avoided GDP losses enhance economic performance thereby raising tax revenues. Nonetheless, the source of the additional wealth cannot be directly attributed to the GDP effect, which renders the added tax revenues politically more ambiguous. Simply put, Oil-GDP induced wealth does not conveniently form itself into resource pools that policy makers can "earmark" to support renewables and other non-fossil technologies. And although the empirical coefficients we use are amply supported in the literature, Oil-GDP induced wealth gains are by their nature more speculative and future oriented. In view of these potential hurdles, we urge policy makers to further verify the issues we present and then, if warranted, implement them through a system of Oil-GDP credits, certificates or similar vehicle.

The Oil-GDP relationship has generally been stable over the last half century. While questions remain about its linearity and possible asymmetry, we do not believe these significantly affect the general message of our analysis: that required investments to deploy RE are significantly offset by avoided Oil-GDP losses. Using US-EIA forecasts, we approximate that our offset estimates translate to an average avoided loss in the range of $\$ 350 / \mathrm{kW}$ of additional renewables in the US and EU. If supported by further research, this presents possibly the most powerful economic driver for further RE investments to date. 


\section{References}

Awerbuch, S. [2004a], "Portfolio-Based Electricity Generation Planning: Policy Implications for Renewables and Energy Security," SPRU, U-Sussex, working paper.

Awerbuch, S. [2004b], "Renewable Energy: Creating a Level-Playing Field”, Intelligent Policy Options: European Conference for Renewable Energy, Berlin: January 19-21; http://www.managenergy.org/archive/me20jan2004.jsp\#panel2d

Awerbuch, [2003a], Is gas really cheapest? Modern Power Systems, p. 17-19.

Awerbuch, S., [2003b], Determining the real cost: Why renewable power is more cost-competitive than previously believed, Renewable Energy World, http://www.jxj.com/magsandj/rew/2003_02/real_cost.html

Awerbuch, S. [2000], Investing in Photovoltaics, Risk Accounting and New Technology, Energy Policy, 28, 1023-1035.

Awerbuch, S. [1995], Market-Based IRP: It's Easy!!!, The Electricity Journal, 8, 3, 50-67.

Awerbuch, S. [1993], The Surprising Role of Risk and Discount Rates in Utility Integrated-Resource Planning, The Electricity Journal, 6, 3, 20-33.

Awerbuch, S. [1992], Surrebuttal Testimony, State of Vermont Public Service Board, Docket 5270-CV-1, Exhibit SA-19.

Awerbuch, S. and Berger, M. [2003], EU Energy Diversity and Security: Applying Portfolio Theory to Electricity Planning and Policy-Making, Paris: International Energy Agency, February 2003, http://library.iea.org/dbtw-wpd/textbase/papers/2003/port.pdf

Balke, N.S., Brown, S.P.A., Yücel, M.K. [2002], Oil Price Shocks and the U.S. Economy: Where Does the Asymmetry Originate?, The Energy Journal, 23, 3, 27-52.

Bernanke, B.S., Gertler, M., Watson, M. [1997], Systematic Monetary Policy and the Effects of Oil Price Shocks, Brookings Papers on Economic Activity, 1, 91-157.

Bolinger, M., Wiser, R., Golove W. [in press], Accounting for fuel price risk when comparing renewable to gasfired generation: the role of forward natural gas prices, Energy Policy, 2004.

Brealey, R. and Myers, S.C. [1996], Principles of Corporate Finance, Fifth Edition, New York, McGraw Hill.

Brown, S.P.A., [2003], U.S. Natural Gas Markets in Turmoil, Testimony Prepared for a Hearing on The Scientific Inventory of Oil and Gas Resources on Federal Lands, Committee on Resources, U.S. House of Representatives, June 19.

Brown, S.P.A. and Yücel, M.K. [2002], Energy Prices and Aggregate Economic Activity: An Interpretative Survey, Quarterly Review of Economics and Finance, 42, 2, 193-208.

Bruno, M., Sachs J., [1982], Input Price Shocks and the Slowdown in Economic Growth. The Case of U.K. Manufacturing, Review of Economic Studies, 49, 679-705.

Burbidge, J., Harrison, A. [1984], Testing for the Effects of Oil-Price Rises Using Vector Autoregression, International Economic Review, 25, 459-484

Business Journals [2004], http://www.businessjournals.com/artman/publish/article 583.shtml

Business Week, [2004], \$50 Oil: A Spreading Slick of Pain, By Amey Stone, September 29. Business Week, [2004], Stocks End Higher as Oil Prices Fall, (Market Snapshot), August 25.

BW Online, [2003], How Global Growth Could Skid on Oil, By David Fairlamb, January 24, http://www.businessweek.com/bwdaily/dnflash/jan2003/nf20030124 7580.htm

CNN [2004] Oil spike II, By Mark Gongloff, CNN/Money senior writer, July 27, http://money.cnn.com/2004/07/27/markets/oil/?cnn=yes 
US Congressional Budget Office [1981], The Effects of OPEC Oil Pricing On Output, Prices, and Exchange Rates in the United States and Other Industrialized Countries.

Darby, M.R. [1982], The Price of Oil and World Inflation and Recession, The American Economic Review, 72 , 4, 738-751.

Davis, S.J., Haltiwanger, J. [2001], Sectoral job creation and destruction responses to oil price changes, Journal of Monetary Economics, 48 3, 465-512.

DTI, (Department of Trade and Industry) [2003], Options for a Low Carbon Future, London, June.

EIA (Energy Information Administration) [2003], Analysis of a 10-percent Renewable Portfolio Standard, Washington, DC, SR/OIAF/2003-01.

EIA [2002], Impacts of a 10-Percent Renewable Portfolio Standard, Washington, DC, SR/OIAF/2002-03.

EIA [2002], http://www.eia.doe.gov/oiaf/economy/energy price.html, 07/18/2002

EIA [2001], Analysis of Strategies for Reducing Multiple Emissions from Electric Power Plants: Sulfur Dioxide, Nitrogen Oxides, Carbon Dioxide, and Mercury and a Renewable Portfolio Standard (ERRATA), Washington, DC, SR/OIAF/2001-03.

EREC (European Renewable Energy Council) [2004], Renewable energy target for Europe 20\% by 2020, http://www.erec-renewables.org/documents/Berlin_2004/targets/EREC_Targets_2020_def.pdf

Ferderer, J. P. [1996], Oil Price Volatility and the Macroeconomy, Journal of Macroeconomics 18, 1, Winter, 126.

Financial Times [2004], Getting a measure of the impact of rising oil prices, Oct. 11. p. 34.

Financial Times [2004], Oil cost forces IMF to cut outlook: Fund warns world economic growth under threat: Director calls for use of alternative energy, by Andrew Balls, Sep 30, p. 1.

Finn, M.G. [2000], Perfect Competition and the Effects of Energy Price Increase on Economic Activity, Journal of Money, Credit and Banking, 32, 400-416.

G-8 [2001], Renewable Energy Task Force, Final Report, Paris: IEA. http://www.renewabletaskforce.org/pdf/G8 report.pdf

Gisser, M., Goodwin, T.H. [1986], Crude oil and the macroeconomy: Tests of some popular notions. Journal of Money, Credit and Banking, 18, 1, 95-103.

Greene, D.L., Tishchishyna, N.I. [2000], Costs of Oil Dependence: A 2000 Update. Oak Ridge, Tenn.: Oak Ridge National Laboratory.

Hamilton, J.D., Herrera, A.M. [2004], Oil Shocks and Aggregate Macroeconomic Behavior: The Role of Monetary Policy, Journal of Money, Credit and Banking, 36, 265-286.

Hamilton, J.D. [2003], What is an oil shock? Journal of Econometrics 113, 363-398.

Hamilton, J.D. [2000], What is an oil shock? NBER Working Paper 7755.

Hamilton, J.D. [1996], This is what happened to the oil price-macroeconomy relationship, Journal of Monetary Economics, 38, 215-220.

Hamilton, J.D. [1988], A Neoclassical Model of Unemployment and the Business Cycle, Journal of Political Economy, 96, 3, 593-617.

Hamilton, J.D. [1983], Oil and the Macroeconomy since World War II, Journal of Political Economy, 91, 2, 228-248.

Hooker, M.A. [1996], What happened to the oil price-macroeconomy relationship? Journal of Monetary Economics, 38, 195-213.

Huntington, H.G. [1998], Crude Oil Prices and U.S. Economic Performance: Where Does the Asymmetry Reside?, The Energy Journal, 19, 4, 107-132. 
IEA [2004], Analysis of the Impact of High Oil Prices on the Global Economy, http://ibrary.iea.org/dbtwwpd/textbase/papers/2004/high_oil_prices.pdf

IEA [2000], World Energy Outlook 2000, Paris, OECD/IEA

IEA/NEA/OECD, [1998] The Cost of Generating Electricity, Paris: International Energy Agency and the Nuclear Energy Agency.

Jones, C.M., Kaul, G. [1996], Oil and the Stock Markets, The Journal of Finance, 51, 2, 463-491.

Jones, D.W., Leiby P.N. [1996], The Macroeconomic Impacts of Oil Price Shocks: A Review of Literature and Issues. Oak Ridge, Tenn.: Oak Ridge National Laboratory.

Jones, D. W., Leiby, P.N., Paik, I.K. [2004], Oil Price Shocks and the Macroeconomy: What Has Been Learned Since 1996, The Energy Journal, 25, 2, 1-32.

Kahn, E., Stoft, S. [1993] (unpublished draft), Analyzing Fuel Price Risks Under Competitive Bidding, Berkeley: Lawrence Berkeley National Laboratory.

Lee, K., Ni, Shwan, Ratti, R.A. [1995], Oil Shocks and the Macroeconomy: The Role of Price Variability, Energy Journal, 16, 39-56.

Leiby, P. [2004], Impacts of Oil Supply Disruption in the United States, Presentation at the IEA/ASEAN Workshop “Oil Supply Disruption Management Issues”, Cambodia, 5-8 April 2004.

Leiby, P. [2002], “Oil Use and U.S. Energy Security Problems and Policy Responses,” Washington DC: Symposium on U.S. Energy Security, Resources for the Future, January 28, 2002 http://www.rff.org/rff/Events/AST28/loader.cfm?url=/commonspot/security/getfile.cfm\&PageID=6474

Lind, R.C. [1982], A Primer on the Major Issues Relating to the Discount Rate for Evaluating National Energy Options, in: Robert C. Lind, Kenneth Arrow, et. al. (Eds.) Discounting for Time and Risk in Energy Policy, DC: Resources for the Future, (Johns Hopkins University Press).

Lovins, A.B., Datta, E.K., Bustnes, O., Koomey, J. G., Glasgow, N.J. [2004], Winning the Oil Endgame, Snowmass, CO: Rocky Mountain Institute

Mork, K.A., Olsen, O. and Mysen, H.T. [1994], Macroeconomic responses to oil price increases and decreases in seven OECD countries. Energy Journal 15, 4, 19-35.

Mork, K. [1989], Oil and the Macro-economy, When Prices Go Up and Down: An Extension of Hamilton's Results, Journal of Political Economy, 97, 3, 740-744.

Mory, J.F. [1993], Oil Prices and Economic Activity: Is the Relationship Symmetric?, The Energy Journal, 14, 4, 151-162.

Nogee, A. [2003], Renewable energy and natural gas: from crisis to opportunity, Presentation at the EESI Briefing, Washington, DC, July 14.

Papapetrou, E. [2001], Oil price shocks, stock market, economic activity and employment in Greece, Energy Economics, 23, 5, 511-532.

Reuters/Planetark [2001], UPDATE, “US energy costs pose recession risk - Abraham,” by Tom Doggett, March 21, 2001, www.planetark.org/dailynewsstory.cfm?newsid $=10170$

Rotemberg, J.J., Woodford, M. [1996], Imperfect Competition and the Effects of Energy Price Increases on Economic Activity, Journal of Money, Credit, and Banking, 28, 4, Part 1, 550-577.

Sadorsky, P. [2003], The macroeconomic determinants of technology stock price volatility, Review of Financial Economics, 12, 191-205.

Sadorsky, P. [1999], Oil price shocks and stock market activity, Energy Economics 2, 449-469.

Sauter, R. and Awerbuch, S. [2002], The Oil-GDP effect: A Survey and Implications for Renewables, IEA Research Report, Paris: International Energy Agency.

Tatom, J.A. [1993], Are there useful lessons from the 1990-91 oil price shock?, Energy Journal, 14, 4, $129-141$. 
The Economist,

- [2004], Pouring oil on the flames, How would financial markets react if the oil price stays stubbornly high? (Global Agenda), Aug 20th .

- [2004], How should central banks respond to a rise in oil prices? Jun 10th.

- [2002], Flaring Up? Might recovery around the world be checked by dearer oil? April 11.

Toman, Michael A. [2002], International Oil Security: Problems and Policies, Resources for the Future, Issue Brief No. 02-04, January.

Union of Concerned Scientists

- Fact Sheet, [2004], Renewing America's Economy: A 20 Percent National Renewable Electricity Standard Will Create Jobs and Save Consumers Money. Cambridge, Mass; September. www.ucsusa.org/clean_energy/renewable_energy/page.cfm?pageID=1505.

- Fact Sheet [2004], Renewable Energy Can Help Ease Natural Gas Crunch. Cambridge, Mass; March. www.ucsusa.org/clean energy/renewable energy/page.cfm?pageID $=1370$

- Fact Sheet, [2003], Renewable Energy Can Help Alleviate Natural Gas Crisis.

- [2002], Renewing Where We Live: A National Renewable Energy Standard Will Benefit America's Economy. Cambridge, Mass., September.

- [2002], Renewing Where We Live, Cambridge, Mass. February.

Wiser, R., Bolinger, M., St. Clair, M. [2004], Risky Business: Alleviating High Natural Gas Prices through Increased Renewable Energy and Energy Efficiency Investments, Lawrence Berkeley National Laboratory Draft report, November.

Yang, C.W., Hwang, M.J., Huang, B.N. [2002], An analysis of factors affecting price volatility of the US oil market, Energy Economics 24, 107-119.

Zervos, A. [2004], Keynote Address, European Conference for Renewable Energy, Berlin, 19-21 January. 